NBER WORKING PAPER SERIES

\title{
CAPITAL ACCOUNT LIBERALIZATION, THE COST OF CAPITAL, AND ECONOMIC GROWTH
}

\author{
Peter Blair Henry \\ Working Paper 9488 \\ http://www.nber.org/papers/w9488 \\ NATIONAL BUREAU OF ECONOMIC RESEARCH \\ 1050 Massachusetts Avenue \\ Cambridge, MA 02138 \\ February 2003
}

This paper was prepared for the session, "Debt, Equity, and Financial Openness" at the American Economic Association meetings in Washington, D.C. on January 4, 2003. A slightly condensed version will appear in the American Economic Review, Papers and Proceedings, May 2003. I am grateful for financial support from an NSF CAREER Award and the Stanford Institute of Economic Policy Research (SIEPR). I thank Sandy Darity, John McMillan and Linda Tesar for comments. The views expressed herein are those of the authors and not necessarily those of the National Bureau of Economic Research.

(C)2003 by Peter Blair Henry. All rights reserved. Short sections of text not to exceed two paragraphs, may be quoted without explicit permission provided that full credit including notice, is given to the source. 
Capital Account Liberalization, The Cost of Capital, and Economic Growth

Peter Blair Henry

NBER Working Paper No. 9488

February 2003

JEL No. E0, F0, G0

\section{$\underline{\text { ABSTRACT }}$}

Three things happen when emerging economies open their stock markets to foreign investors. First, the aggregate dividend yield falls by 240 basis points. Second, the growth rate of the capital stock increases by an average of 1.1 percentage points per year. Third, the growth rate of output per worker rises by 2.3 percentage points per year. Since the cost of capital falls, investment booms, and the growth rate of output per worker increases when countries liberalize the stock market, the increasingly popular view that capital account liberalization brings no real benefits seems untenable.

Additional information regarding the "Time Series of Major Policy Reforms in LDCs" is available online: http://www.nber.org/appendices/w9488.appenidx1.pdf

Peter Blair Henry

Stanford University

Graduate School of Business

Littlefield 277

Stanford, CA 94305-5015

and NBER

abhenry@stanford.edu 


\section{Introduction}

Capital account liberalization was once seen as an inevitable step along the path to economic development for poor countries. Liberalizing the capital account, it was said, would permit financial resources to flow from capital-abundant countries, where expected returns were low, to capital-scarce countries, where expected returns were high. The flow of resources into the liberalizing countries would reduce their cost of capital, increase investment, and raise output (Fischer, 1998; Summers, 2000). The principal policy question was not whether to liberalize the capital account, but when - before or after undertaking macroeconomic reforms such as inflation stabilization and trade liberalization (McKinnon, 1991). Or so the story went.

In recent years intellectual opinion has moved against liberalization. Financial crises in Asia, Russia and Latin America have shifted the focus of the conversation from when countries should liberalize to if they should do so at all. Opponents of the process argue that capital account liberalization does not generate greater efficiency. Instead, liberalization invites speculative hot money flows and increases the likelihood of financial crises with no discernible positive effects on investment, output, or any other real variable with nontrivial welfare implications (Bhagwhati, 1998; Rodrik, 1998; Stiglitz 2002).

While opinions about capital account liberalization are abundant, facts are relatively scarce. This paper tries to increase the ratio of facts to opinions. In the late 1980s and early 1990s a number of developing countries liberalized their stock markets, opening them to foreign investors for the first time. These liberalizations constitute discrete changes in the degree of capital account openness, which allow for a positive 
empirical description of the cost of capital, investment, and growth during liberalization episodes.

Figure 1 previews the central message that the rest of this paper develops in more detail. The cost of capital falls when developing countries liberalize the stock market. Since the cost of capital falls, investment should also increase, as profit maximizing firms drive down the marginal product of capital to its new lower cost. Figure 2 is consistent with this prediction. Liberalization leads to a sharp increase in the growth rate of the capital stock. Finally, as a direct consequence of growth accounting, the increase in investment should generate a temporary increase in the growth rate of output per worker. Figure 3 confirms that the growth rate of output per worker rises in the aftermath of liberalization.

While the figures do no harm to the efficiency view of capital account liberalization, a number of caveats are in order. For example, it is legitimate to interpret a fall in the dividend yield (Figure 1) as a decline in the cost of capital, if there is no change in the expected future growth rate of dividends at the time of liberalization. But stock market liberalizations are usually accompanied by other economic reforms that may increase the expected future growth rate of output and dividends (Henry, 2000a,b). Because liberalizations do not occur in isolation, it is important to think carefully about how to interpret the data. Neoclassical theory provides a good starting point for framing the issues.

\section{Theory}

There are two components to a country's cost of capital: the risk-free rate and the 
equity premium. Theory suggests that both will fall when a poor country liberalizes. The following partial equilibrium, mean variance arguments based on Stulz (1999) make the central points most succinctly.

Assume a small country whose equity market is completely segmented from world equity markets. Also assume that all investors in the world have the same constant relative risk aversion and care only about the expected return and variance of their investment. Let $E\left[\tilde{R}_{M}\right]$ denote the equilibrium required rate of return on the aggregate domestic stock market before liberalization and let $r_{f}$ denote the domestic risk-free interest rate. Define the price of risk as follows: the aggregate risk premium, $E\left[\tilde{R}_{M}\right]-r_{f}$, divided by the variance of the aggregate return on the market, $\operatorname{VAR}\left(\tilde{R}_{M}\right)$. Under our assumptions, the price of risk in the small country before liberalization is a constant, $\mathrm{T}$. It follows that

$$
E\left[\tilde{R}_{M}\right]=r_{f}+\mathrm{T} \operatorname{Var}\left(\tilde{R}_{M}\right)
$$

Now consider what happens to the required rate of return when the country opens its stock market to the rest of the world and also allows its residents to invest abroad. Assume that the mean and variance of domestic dividends are unaltered by the liberalization. Let $E\left[\tilde{R}_{M}^{*}\right]$ denote the required rate of return on the market after liberalization and let $E\left[\tilde{R}_{W}\right]$ be the required rate of return on the world equity market. With completely open capital markets, the world risk-free rate, $r_{f}^{*}$, becomes the relevant interest rate. The risk premium on the domestic stock market will now depend on the following two factors: (1) the beta of the domestic stock market with the world stock market, $\beta_{M W}$, and (2) the world risk premium, $E\left[\tilde{R}_{W}\right]-r_{f}^{*}$. Following liberalization it 
must be the case that

$$
E\left[\tilde{R}_{M}^{*}\right]=r_{f}^{*}+\beta_{M W}\left(E\left[\tilde{R}_{W}\right]-r_{f}^{*}\right)
$$

Since the liberalizing country is small, adding its stock market to the world market portfolio has a negligible effect on the variance (and hence the risk premium) of the world market portfolio. It follows that $\left(E\left[\tilde{R}_{W}\right]-r_{f}^{*}\right)=\mathrm{T} V A R\left(\tilde{R}_{W}\right)$. Using this fact, the definition of $\beta_{M W}$, and a little bit of algebra, one can show that after liberalization the required rate of return on the domestic stock market is given by:

$$
E\left[\tilde{R}_{M}^{*}\right]=r_{f}^{*}+\mathrm{T} \operatorname{Cov}\left(\tilde{R}_{M}, \tilde{R}_{W}\right)
$$

Subtracting equation (1) from equation (3) gives the difference in the post- and pre-liberalization required rates of return:

$$
\Delta E\left[\tilde{R}_{M}\right]=\left(r_{f}^{*}-r_{f}\right)+\mathrm{T}\left[\operatorname{Cov}\left(\tilde{R}_{M}, \tilde{R}_{W}\right)-\operatorname{Var}\left(\tilde{R}_{M}\right)\right]
$$

Since poor countries have lower capital-to-labor ratios than rich countries, we would expect that $r_{f}>r_{f}^{*}$. Hence the first term on the right-hand side of (4) is negative. Next, consider the change in the equity premium. For every country in the sample, $\operatorname{Cov}\left(\tilde{R}_{M}, \tilde{R}_{W}\right)$, the covariance of the local market with the world market, is less than $\operatorname{Var}\left(\tilde{R}_{M}\right)$, the variance of the local market (Stulz, 1999). Hence the second term is also negative. The central result follows: Liberalization reduces the cost of capital.

\section{Evidence}

Identifying liberalization dates is the first step in determining whether liberalization reduces the cost of capital in practice. Since markets are forward-looking, the most important question is when does the market first learn of a credible, impending 
liberalization? In principle, identifying a liberalization date simply involves finding the date on which the government declares that foreigners may purchase domestic shares. In practice, the liberalization process is not so transparent. In many cases, there is no obvious government declaration or policy decree that one can point to. When there is no salient liberalization decree, I infer the first date on which foreigners could hold domestic shares from the first date on which a closed-end country fund was established. ${ }^{1}$ Table 1 presents a list of the 18 countries in the sample, the date of their first stock market liberalization, and the means by which they liberalized. For example, the table shows that the modal means of liberalization occurred through the establishment of a closed-end country fund.

The establishment of a country fund in particular, and stock market liberalizations in general, may seem like a narrow way to define capital account liberalization relative to the broader liberalization indicators that are employed elsewhere in the literature (Edison, Klein, Ricci, and Sloek, 2002). But it is precisely the narrowness of stock market liberalizations that make them more useful for the purpose at hand. Studies that use broad liberalization indicators focus on cross-sectional data, examining the long-run correlation between average openness and average investment. Examining the correlation between average openness and investment tells us whether investment rates are permanently higher in countries with capital accounts that are more open. The problem with this approach is that neoclassical theory makes no such prediction.

What the theory does predict is that capital-poor countries will experience a temporary increase in investment when they liberalize. Hence, the relevant issue is not

\footnotetext{
${ }^{1}$ See Henry (2000a) and Bekaert and Harvey (2000) for further details on dating liberalizations.
} 
whether countries with open capital accounts have higher investment rates, but whether investment increases in the immediate aftermath of liberalizations. The most transparent way of testing the prediction is to compare investment rates during liberalization episodes with investment rates during non-liberalization periods. Because they constitute a radical shift in the degree of capital account openness, stock market liberalizations provide ideal natural experiments for confronting the theory with data.

\section{A. Cost of Capital}

Having identified dates on which liberalizations occur, the key question is how to detect empirically whether the cost of capital falls. The cost of capital is the equilibriumrequired rate of return on the stock market. Therefore, if liberalization reduces the cost of capital, we should see a one-time revaluation of stock prices when liberalizations occur (Henry, 2000a). For the descriptive exercise here, it is more convenient to use annual dividend yields.

Again, Figure 1 is consistent with the view that liberalization reduces the cost of capital. The figure plots the average aggregate dividend yield across the 18 liberalizing countries in event time (year [0] is the year of liberalization). The average dividend yield falls by roughly 240 basis points-from an average level of 5.0 percent in the 5 years prior to liberalization to an average of 2.6 percent in the five years following liberalization.

Figure 1 is, of course, also consistent with other interpretations. Recall that the dividend yield equals the required rate of return on equity minus the expected growth rate of dividends: 
$\frac{D}{P}=E\left[\tilde{R}_{M}\right]-g$

Section I explains why liberalization reduces $E\left[\tilde{R}_{M}\right]$. Here, the variable under scrutiny is $g$, the expected growth rate of dividends. If $g$ does not change when liberalizations occur, then a fall in the dividend yield implies a fall in the cost of capital. Because liberalizations are part of a general process that involves substantial macroeconomic reforms, however, there is a strong possibility that they are associated with changes in $g$. Economic reforms do have significant effects on the stock market (Henry, 2002). But the financial effects of liberalization remain statistically and economically significant, after controlling for contemporaneous reforms (Henry 2000a, Bekaert and Harvey, 2000).

\section{B. Investment}

If liberalizations reduce the cost of capital then we should also see more investment. Figure 2 shows that the growth rate of the capital stock rises by 1.1 percentage points in the aftermath of liberalizations - from an average of 5.4 percent per year in the pre-liberalization period to an average of 6.5 percent in the post-liberalization period - but Figure 2 is subject to the same criticism as Figure 1. Does investment increase because liberalization reduces the cost of capital? Or, is the entire effect driven by a reform-induced rise in $g$ ? Investment does increase following major reforms, but the effect of liberalization on investment remains significant, after controlling for reforms (Henry, 2000b).

\section{Growth}


Since the growth rate of the capital stock increases, the growth rate of output per worker should also rise. Figure 3 confirms that the growth rate of output per worker rises by 2.3 percentage points - from an average of 1.4 percent per year in the preliberalization period to an average of 3.7 percent per year in the post-liberalization period. On the one hand, there is nothing surprising about Figure 3. Whereas Figures 1 and 2 document behavioral responses of prices and quantities of capital to liberalization, Figure 3 simply provides a mechanical check of the standard growth accounting equation: $\hat{Y}=\hat{A}+\alpha \hat{K}+(1-\alpha) \hat{L}$

Where a circumflex over a variable denotes the change in the natural log of that variable.

The interesting point about Figure 3 is that the increase in the growth rate of output per worker is too large to be explained by the increase in investment. A few simple calculations illustrate the point. The elasticity of output with respect to capital, $\alpha$, is typically around 0.33 . So, based on Figure 2 , we would expect the growth rate of output per worker in the post-liberalization period to be about 0.363 (0.33 times 1.1) percentage points higher. But Figure 3 displays a 2.3 percentage point increase in the growth rate of output per worker. All else equal, a 1.1 percentage point increase in the growth rate of the capital stock can produce a 2.3 percentage point increase in the growth rate of output per worker only if the elasticity of output with respect to capital is on the order of 2 !

Bekaert, Harvey, and Lumsdaine (2001) find that the increase in growth due to liberalization is slightly larger than 1 percentage point after controlling for a number of variables. Nevertheless, their finding still requires an elasticity of output with respect to capital that is greater than 1. Their paper does not address the inconsistency of their 
finding with standard production theory. I do so here.

The missing piece is, of course, Total Factor Productivity (TFP) growth. Equation (6) shows that any increase in the rate of growth of output that is not accounted for by an increase in the growth rate of capital and labor must be the result of an increase in $\hat{A}$, the growth rate of technology. In the current context, it is important to remember that the pure theory of capital account liberalization focuses exclusively on capital accumulation. Technological change and TFP growth do not enter into the story. Therefore, one cannot automatically claim that liberalization is also responsible for the increase in TFP growth.

Now, it is true that if liberalization increases the allocative efficiency of domestic investment, it will also raise TFP growth without any need for technological change. However, it is not obvious why capital account liberalization, a policy change directed at increasing international allocative efficiency, would have any effect on domestic allocative efficiency (Chari and Henry, 2002a; Gourinchas and Jeanne, 2002). But if theories of capital account liberalization cannot explain the increase in TFP growth, what can?

\section{Open Questions}

The simplest answer is that the economic reforms, which make it difficult to interpret the fall in the dividend yield as a decrease in the cost of capital, are also responsible for the increase in TFP growth. While we typically interpret $\hat{A}$ as the growth rate of technological progress, any economic reform that raises the efficiency of a given 
stock of capital and labor will also increase $\hat{A}$, even in the absence of technological change.

The argument is not that capital account liberalization-based theories are utterly incapable of explaining increases in TFP growth. To the contrary, one can tell augmented stories in which capital account liberalization does induce technological change. For example, liberalization may ease binding capital constraints, thereby enabling firms to adopt technologies that they could not finance prior to the liberalization. It is also possible that increased risk sharing encourages investment in riskier, higher growth technologies in the spirit of Obstfeld (1994).

The point is that the developing countries in this sample may have increased their rate of adoption of new production technologies during the late 1980s and early 1990s but, if that is the case, it is not immediately apparent from aggregate data (Figures 1 through 3). In contrast, aggregate data are completely consistent with the preponderance of readily observable evidence that the countries engaged in substantial economic reform. Occam's razor argues for the simple, reform-driven explanation of TFP growth over more elaborate capital-account-liberalization- based stories.

Having said that, the only way to completely resolve the issue is to confront it with data that are capable of distinguishing between competing theories. Recent studies of liberalization that move from aggregate to firm-level data show the way forward. For example, Chari and Henry (2002b) provide evidence that liberalization does increase risk sharing. Examining whether the increase in risk sharing induces firms to adopt new production technologies would provide a direct test of capital-account-liberalizationbased explanations of TFP growth. 


\section{Conclusion}

When developing countries liberalize the stock market, their cost of capital falls, investment booms, and the growth rate of output per worker increases. While these facts cast doubt on the view that capital account liberalization brings no real benefits, there are many important questions to which the evidence does not speak. For some of these questions, such as do liberalizations cause crises, aggregate data may yet prove useful. For other questions, aggregate data are simply too coarse to provide precise answers. Moving the technological frontier to firm-level data should enhance our general understanding of the process by which the effects of liberalization are transmitted to the real economy. 


\section{References}

Bekaert, Geert and Harvey, Campbell. "Foreign Speculators and Emerging Equity Markets," Journal of Finance, 2000, Vol. 55, No. 2, pp. 565-613.

Bekaert, Geert; Harvey, Campbell and Lundblad, Christian. "Does Financial Liberalization Spur Growth?” NBER Working Paper No. 8245, 2001.

Bhagwati, Jagdish. “The Capital Myth,” Foreign Affairs, May/June 1998, pp. 7-12.

Chari, Anusha and Henry, Peter Blair. "Capital Account Liberalization: Allocative Efficiency or Animal Spirits.” NBER Working Paper No. 8908, 2002a.

Chari, Anusha and Henry, Peter Blair. "Risk Sharing and Asset Prices: Evidence From a Natural Experiment." Stanford University Working Paper, 2002b.

Edison, Hali; Klein , Michael; Ricci, Luca and Sloek, Torsten. "Capital Account Liberalization and Economic Peformance: Survey and Synthesis." NBER WP\# 9100, 2002.

Fischer, Stanley. "Capital Account Liberalization and the Role of the IMF," Princeton Essays in International Finance 207, 1998, pp. 1-10.

Gourinchas, Pierre Olivier and Jeanne, Olivier. "On the Benefits of Capital Account Liberalization. Princeton University Working Paper, 2002.

Henry, Peter Blair. "Stock Market Liberalization, Economic Reform, and Emerging Market Equity Prices,” Journal of Finance, 2000a, Vol. 55, No. 2, pp. 529-64.

Henry, Peter Blair. "Do Stock Market Liberalizations Cause Investment Booms?” Journal of Financial Economics, 2000b, Vol. 58, Nos. 1-2, pp. 301-334.

Henry, Peter Blair. "Is Disinflation Good for the Stock Market?” Journal of Finance, 2002, Vol. LVII, No. 4, pp. 1617-1648

Kim, E. H., Singal, V. "Stock Market Openings: Experience of Emerging Economies," Journal of Business, 2000, 73, 25-66.

McKinnon, Ronald I. The Order of Economic Liberalization. Johns Hopkins University Press, Baltimore, 1991.

Obstfeld, Maurice. "Risk-taking, global diversification, and growth," Economic Review 84, 1994, pp. 1310-29.

Rodrik, Dani. "Who needs capital account convertibility?” Princeton Essays in International Finance 207, 1998, pp. 55-65. 
Stiglitz, Joseph. Globalization and Its Discontents. W.W. Norton, New York, (2002).

Stulz, René M. "Globalization of Equity Markets and the Cost of Capital." NYSE Working Paper 99-02, 1999.

Summers, Lawrence H. "International Financial Crises: Causes, Prevention, and Cures," American Economic Review, 2000, Vol. 90, No.2, pp. 1-16. 
Table 1. Country Stock Market Liberalization Dates

\begin{tabular}{lcl}
\hline Country & $\begin{array}{l}\text { Year of } \\
\text { Liberalization }\end{array}$ & $\begin{array}{l}\text { Means of } \\
\text { Liberalization }\end{array}$ \\
\hline Argentina & 1989 & Policy Decree \\
Brazil & 1988 & Country Fund \\
Chile & 1987 & Country Fund \\
Colombia & 1991 & Policy Decree \\
India & 1986 & Country Fund \\
Indonesia & 1989 & Policy Decree \\
Jordan & 1995 & Policy Decree \\
Korea & 1987 & Country Fund \\
Malaysia & 1987 & Country Fund \\
Mexico & 1989 & Policy Decree \\
Nigeria & 1995 & Policy Decree \\
Pakistan & 1991 & Policy Decree \\
Philippines & 1986 & Pountry Fund \\
Taiwan & 1986 & Pountry Fund \\
Thailand & 1987 & Country Fund \\
Turkey & 1989 & Policy Decree \\
Venezuela & 1990 & Pimbabwe
\end{tabular}

Notes: The liberalization dates in this table are based on those in Henry (2000a), Bekaert and Harvey (2000), Kim and Singal (2000), and Levine and Zervos (1996). For a detailed discussion about the difficulties involved in selecting liberalization dates See Henry (2000a). 


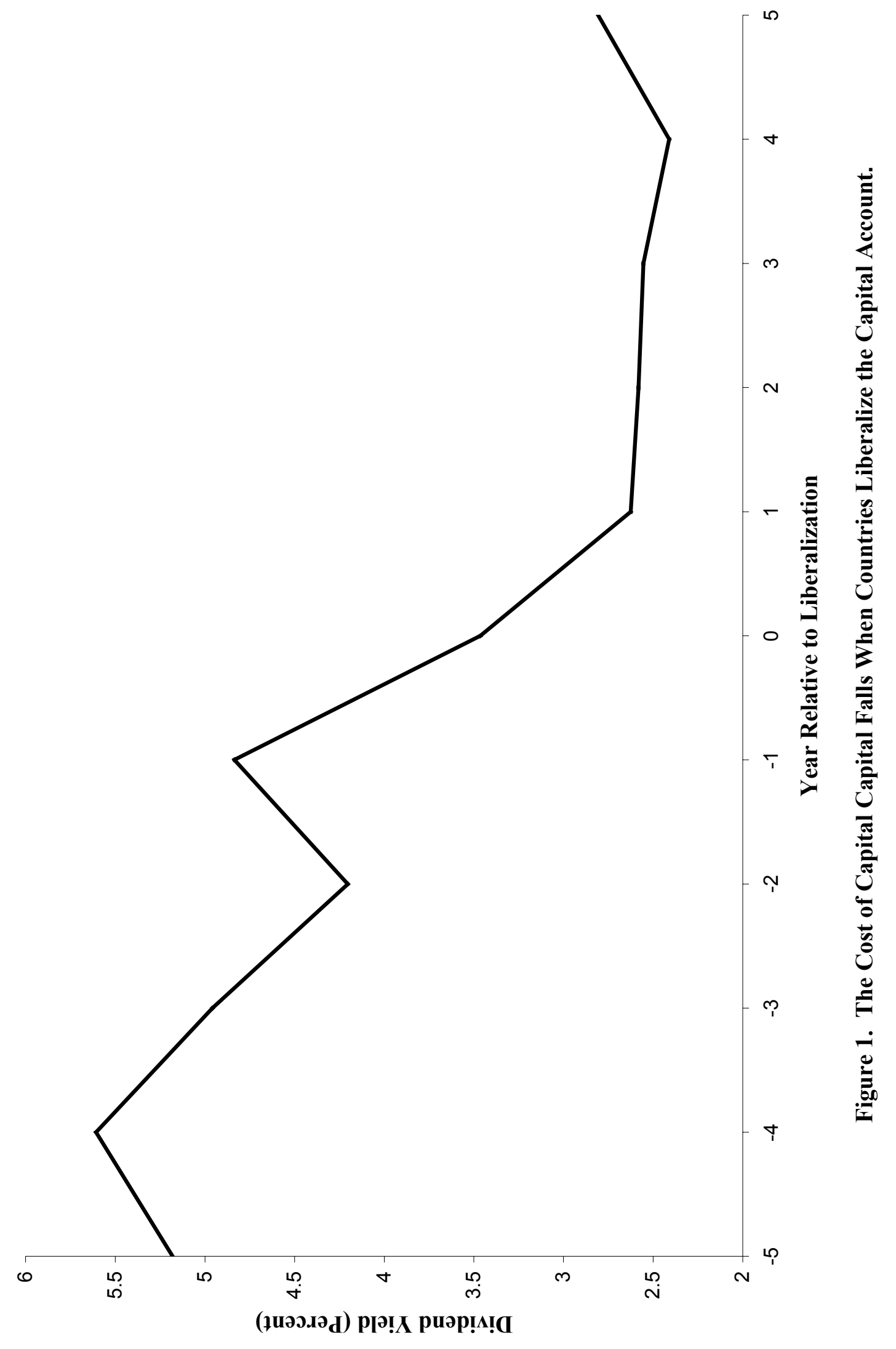




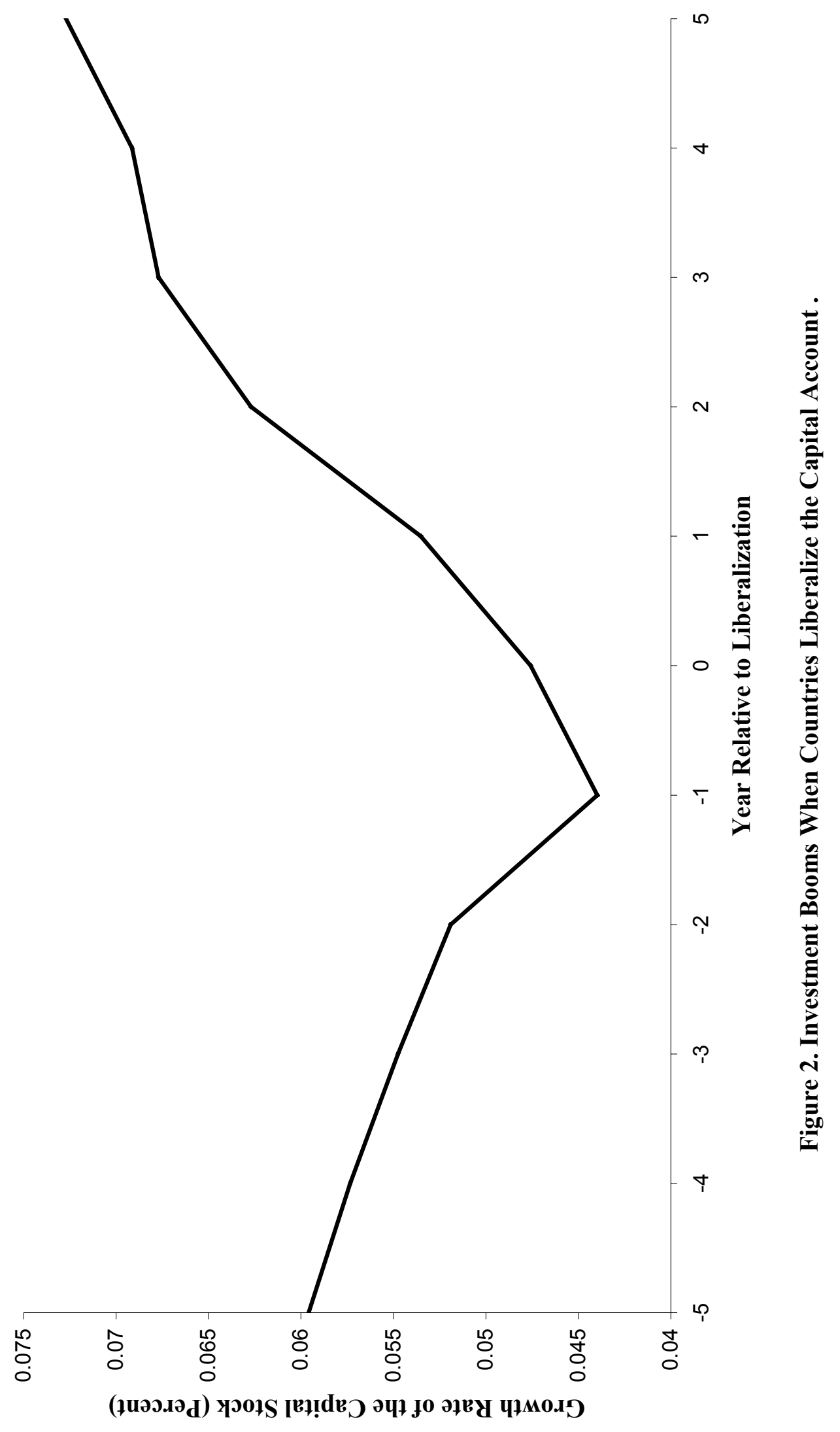




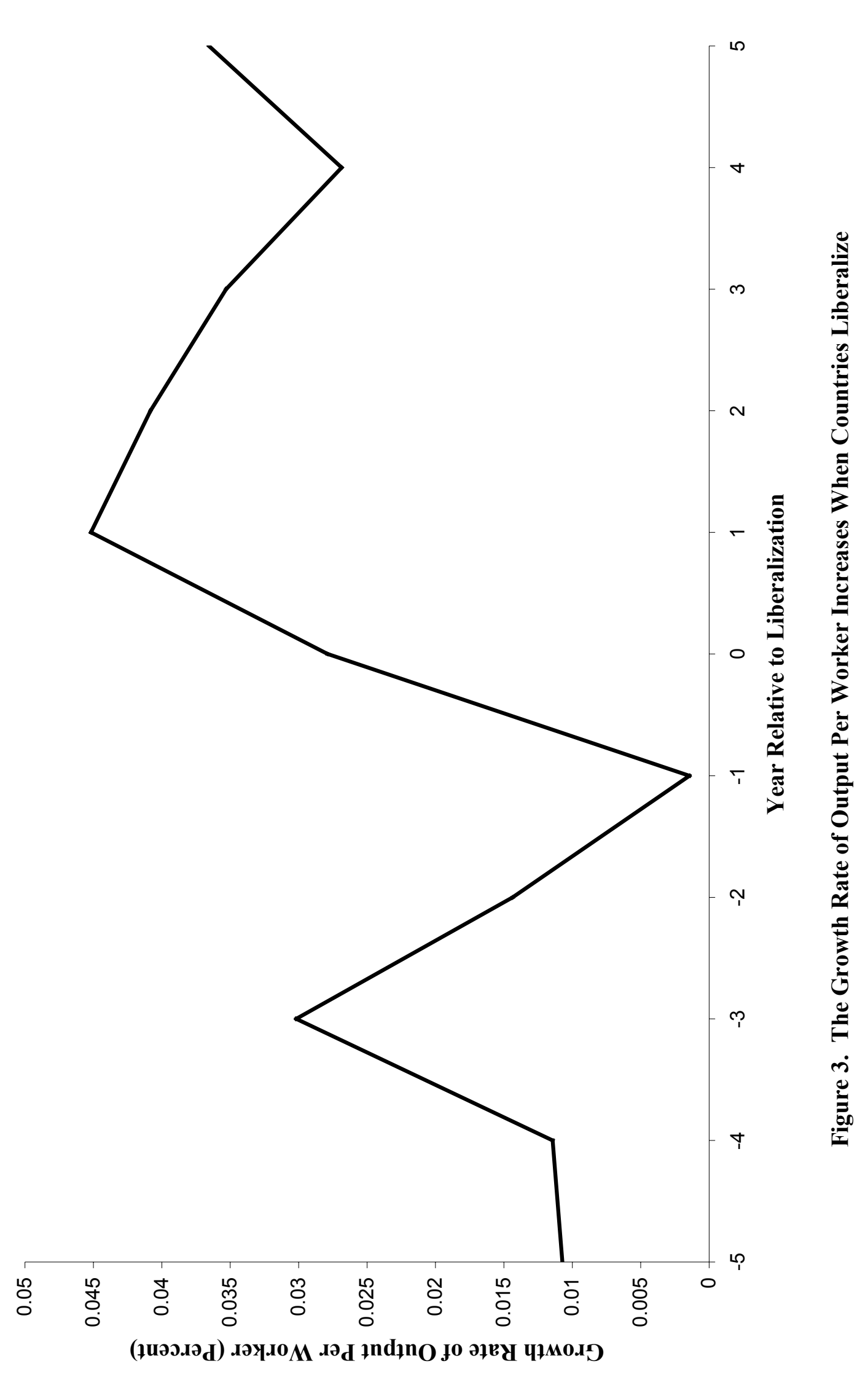

